Kursch, M. (2021). Impact of a one-off demonstration on the use of ICT in the teaching of andragogy students on their change of attitude towards the use of ICT in education, International Journal of Cognitive Research in Science, Engineering and Education (IJCRSEE), 9(1), 121-134.

Original scientific paper

UDK:

004:37.011.22

Received: March, 16.2021.

Revised: April, 09.2021.

doi: $10.23947 / 2334-8496-2021-9-1-121-134$

Accepted: April, 12.2021.

Check for updates

\title{
Impact of a One-Off Demonstration on the Use of ICT in the Teaching of Andragogy Students on Their Change of Attitude Towards the Use of ICT in Education
}

\author{
Martin Kursch ${ }^{1^{*}}$ \\ ${ }^{1}$ Charles University, Prague, Czech Republic; e-mail: martin.kursch@pedf.cuni.cz
}

\begin{abstract}
The research study deals with the issue of attitudes towards the use of ICT in the education of andragogy students. As a method of research, we chose a three-year experiment. The study first surveyed 224 students in andragogical fields - future educators - in order to discover input factors like identifying their relationship to ICT, skills, experience in the field of ICT and frequency of the use of ICT at work. The study further examines four separate variables, representing three dimensions of attitudes (cognitive, conative and emotional) towards the use of ICT in education - the conviction to use ICT in their teaching, the opinion on the impact of the use of ICT on the understanding of curriculum, the opinion on the impact of the use of ICT in teaching and education itself and the tendency to act to recommend the use of ICT in teaching to their colleagues. In the university teaching of students itself, using the didactic method of AIDA on a mathematical problem, the experimental group is the subject of a demonstration of the use of ICT in empirical verification of the results of the task, as opposed to a control group that does not use ICT in teaching. Specifically, the representation of results in MS Excel and the empirical verification of results in a Python-created program are used. The research aims to determine the impact of the demonstration of a one-off use of ICT in teaching on the change of dimensions of attitude towards the use of ICT in education represented by separated variables. Their rate is measured by a 10 -point bipolar scale. The results show $p$ value $(p<0.05)$, which provides evidence that a one-off demonstration of the use of ICT in the teaching of andragogy students is a factor that statistically significantly influences these dimensions of attitude towards the use of ICT in education and thus its overall change, regardless of the gender of the students. The three-year research study confirmed these results in an aggregated experimental group of 112 respondents who were compared with the same aggregated control group.
\end{abstract}

Keywords: ICT in education, Python, AIDA method, attitudes towards the use of ICT in education.

\section{Introduction}

The issue of the use of ICT in education is extensive. Due to the rapid expansion of the use of ICT in all areas of education in recent decades, it has not been enough to form a uniform methodology for the teaching of ICT (Takada et al., 2020). The concept of the use of ICT in teaching can be understood in two ways: ICT as a teaching support tool for mediation of information (e.g., video usage, data projector, mobile devices, internet for searching, etc.) or as a tool for the understanding of curriculum or tool for solving the problem (modelling in applications, creative creation of multimedia content, use of robots, virtualization of reality, simulation, etc.). Teachers, adult educators, lecturers, education advisers and education managers (henceforward we generally use only the term "educators" for all roles) are subject to ever-higher requirements in the field of ICT management and its use in teaching. There are also many concepts of digital competencies, such as DigComp (European Digital Competence Framework 2.0) (Vuorikari et al., 2016). This model works with eight levels of competence from beginner to expert. The aim is for future standardisation of jobs; for example, an employer will be able to say that he requires a certain level of competence. Technological Pedagogical Content Knowledge (TPCK) is one of the general frameworks of the basic knowledge needed to perform the teaching profession. Koehler et al. (2013) seek to apply the TPCK model in the preparation of future teachers. They verify their approach at the Learning Technology Through Design course. In it, students of different specializations learn to prepare (create) ICT-based tutorials together. They propose their own course focused on specific ${ }^{*}$ Corresponding author: martin.kursch@pedf.cuni.cz

(c) (i) 2021 by the authors. This article is an open access article distributed under the terms and conditions of the Creative Commons Attribution (CC BY) license (https://creativecommons.org/licenses/by/4.0/). 
Kursch, M. (2021). Impact of a one-off demonstration on the use of ICT in the teaching of andragogy students on their change of attitude towards the use of ICT in education, International Journal of Cognitive Research in Science, Engineering and Education (IJCRSEE), 9(1), 121-134.

content, a project implementing a specific teaching activity, a website, etc. Students work here in teams in which the roles of all three specializations (TPC) are represented. Together, under the guidance of lecturers, they seek mutual intersections to include all possible views in the resulting work (Brdička, 2009).

It is clear that mere knowledge of ICT is not a sufficient condition for its active use in teaching. If we consider the evolution of teaching methods in the context of the transition from behaviourism, cognitivism and constructivism to connectivism (Siemens, 2005), we come to the paradigm of teaching methods as a comprehensive approach using various sources. And at this point, it is necessary to distinguish the instructional and constructive approach to teaching methods. It is the constructive methods that are more closely linked to the use of ICT as a tool for understanding of curriculum or solving problems. Brdička (2004) aptly points out "that the most important thing for teachers is to understand what is the most effective way of deploying technologies using different teaching procedures. Since it is easier for the instructive, the emphasis must nowadays be mainly on constructive procedures. Only a teacher successfully through the stage of empathy can reach a successful end to the process, i.e., to the innovation itself. At this last stage, it is his task to customize the outline and change his working methods for real." Managing ICT and integrating it into teaching therefore requires certain mastery, knowledge and skills. However, the concept of Education 4.0 in the concept of Kursch and Veteška points to other factors that should be considered to make the use of ICT in education innate by future educators (Kursch and Veteška, 2019). According to them, the factors of initiating their outburst, enthusiasm for the cause and engagement are also important. As part of the university training of andragogy students, these factors could be a trigger for further action in this area. Many studies are looking at the positive effects of the use of ICT in teaching, both for students and teachers (Hardman, 2019; Mlambo, Rambe and Schlebusch, 2020; Coklar, 2013; Cok, 2016; Genlott and Grönlund, 2016); Willis et al., 2019; Hammond, 2017, Garzón et al., 2020); Eger et al., 2020; Chang, Tu and Hajiyev, 2019; Wang, Tigelaar and Admiraal, 2021; Eksail and Afari. 2020), however there are not many studies examining how to induce educators to change attitudes towards the use of ICT, in terms of understanding its true added value in teaching itself from a didactic point of view and increasing their motivation to use ICT in teaching. For example, Tomczyk et al. (2020a) concluded based on research that teachers tend to be more of "techno-optimists". Hanafi et al. (2017) addressed the reasons for the low motivation of university students to participate in the ICT use course in teaching (e.g., due to a lack of experience in ICT). His experimental study examined the impact of the new augmented reality mobile application (MARLA) on the motivation of students to attend an ICT university course. The research consisted of 120 non-technical undergraduates specializing in social sciences with an average age of 19.5 years. They were divided into an experimental group and a control group. The dependant variable was the motivation of students to learn and independent variables were the method of learning and gender. The experimental group used the MARLA app on their mobile devices to adopt one of the course topics - ICT competencies, while the control group used a similar application on their desktop computers. An analysis of covariance was performed which showed that boys were more motivated than girls using a mobile app. On the other hand, no effect attributed to the method of learning was observed. The authors concluded that it is likely that a mobile educational tool can be used to help non-technical college students learn with greater motivation, but its success will depend on proper planning and implementation considering the different needs of boys and girls.

Although the use of ICT in education is very extensive and widely discussed, there are currently many meta-studies that bring undetected discoveries in this area. Zhang, Basham and Yang (2020) conducted a meta-study where he identified and synthesized 71 empirical studies related to the implementation of personalised learning conducted between 2006 and 2019. Meta-study shows positive effects of the use of ICT in personalization of teaching, both for students themselves and teachers. The following technologies appeared in the studies under review: web-based adaptive learning systems, intelligent tutoring systems, educational computer games, virtual reality systems, computerized adaptive assessments, mobile applications and multimedia tools for digital storytelling. In conclusion, it notes that personalisation of learning with the help of ICT is by no means a simple task that can be solved by short-term research or intermittent implementation. Personalisation of teaching with the help of ICT will require decades of joint efforts by different stakeholders to bring a promising innovation of education to reality. Talan (2020) conducted a meta-study of the effects of mobile learning. The main purpose of this meta-study was to determine the impact of mobile learning on students' learning performance. One hundred four studies conducted between 2009 and 2019 that met the criteria for inclusion were subjected to meta-analysis. The study sample consisted of 7568 participants. Results showed that the influence of mobile learning did not change students' learning performance based on the level of education and the period of implementation but changed the study performance based on the subject $(p<0.05)$. This interesting finding confirms that mobile learning effectively targets the content of a particular subject and can increase students' learning 
Kursch, M. (2021). Impact of a one-off demonstration on the use of ICT in the teaching of andragogy students on their change of attitude towards the use of ICT in education, International Journal of Cognitive Research in Science, Engineering and Education (IJCRSEE), 9(1), 121-134.

performance, probably by increasing their motivation and due to mobile platforms being easily available. Eksail and Afari (2020) also found links between teachers' attitudes towards ICT and their use in teaching. His research concluded that the perception of the usefulness of the use of ICT in teaching can improve attitudes towards the use of ICT. A very interesting research of the attitude towards ICT in education was also carried out by Tomczyk et al. (2020b), who tried to answer the question "How does the attitude to New Media influence the evaluation of a new e-learning platform among current and future teachers?" One of his conclusions was that a positive attitude to media in one area of use, e.g., private, is linear with a positive attitude in another area. Snijders et al. (2018) attempted to predict where the use of ICT in the educational process will go. Based on the knowledge from his studies, he predicts that the role and position of the educator will change. Thanks to the massive use of ICT, the traditional approach to teaching is expected to be just one of many ways of education.

\section{Research Review (in Brief)}

Since our department is preparing teachers (our andragogy students are or will be teachers, teachers, adult educators, principals and other roles), we have tried, within our possibilities, to conduct research that would answer the research problem $P$, what is the effect of a one-off demonstration of the use of ICT in teaching andragogy students on their change of attitude towards the use of ICT in the field of education. That is why we have formulated the following three research questions:

- Does a one-off demonstration of the use of ICT in university teaching influence the opinion of andragogy students about the impact of the use of ICT on the understanding of curriculum and education and learning itself?

- Does a one-off demonstration of the use of ICT in university teaching influence the immediate conviction of andragogy students to use ICT in their future teaching?

- Does a one-off demonstration of the use of ICT in university teaching influence the inclination to act to recommend to your colleagues the use of ICT in teaching?

Our choice of a demonstration was to use ICT as a tool for the understanding of curriculum or solving the problem. We were particularly interested in whether the use of ICT, namely the use of MS Excel in data processing and a short Python program in empirical verification of the results of a mathematical task, can have an impact on the change of three dimensions of attitude towards the use of ICT in education. When determining variables, we draw from the theory of attitudes and their dimensions in personality psychology (Nakonečný, 2009, p. 235). The first variable for us is the conviction of students of andragogy to use ICT in their future teaching (their personal emotional fixed opinion about the inclusion of ICT in teaching). This variable represents an emotional dimension (in short, we will call this variable "personal use"). The second variable is the opinion of andragogy students about the impact of the use of ICT in teaching on the understanding of curriculum (in short, we will call this variable "understanding"). This variable represents a cognitive dimension. The third variable is their opinion on the impact of ICT use on education and learning itself (in short, we will call this variable "teaching". This variable also represents a cognitive dimension. The fourth variable is the tendency to act to recommend the use of ICT in teaching to their colleagues (in short, we will call the variable "recommendation"). This variable represents a conative (behavioral) dimension. Recalling the fundamental fact, our research does not have the ambition to examine these variables in a sophisticated way, but to compare their initial value corresponding to the initial state of students and their final value corresponding to the state after the experiment. The research focuses on finding a change in attitude towards the use of ICT in education (or changes in individual dimensions of attitude as a complex phenomenon). With appropriate questions, we check these variables in control and experimental groups before a demonstration of the use of ICT in teaching and thereafter. The variables "personal use", "understanding", "teaching" and "recommendations", which carry the meanings of the dimensions of attitude towards the use of ICT in education in general, cannot be accurately measured, and therefore we choose a relative comparison of their measurement according to the bipolar 10-point scale so that we can easily check their change. We tried to find out whether an appropriate one-off demonstration of the use of ICT in teaching for students of andragogy - current and future educators (in this case, modelling the real situation using a written program that engages these students) will change their dimensions of attitudes towards the use of ICT in education, i.e. the rate of our four separate variables. Our research only measures variable change based on a one-off external stimulus. Nevertheless, in the event of a positive change, it may result, for example, in increasing the chances of andragogy students using ICT in their future practice or changing their long-term views on the use of ICT in education. However, the results should clearly tell us whether the inclusion of the demonstration of the use 
of ICT in the teaching of andragogy students will affect their attitude towards the use of ICT in education. Summing up our research, its starting point is not only past studies more or less confirming the positive effects of ICT on education, self-education and learning, and studies on the effects of ICT use on future teachers, but above all the concept of external influence on changing a person's attitude. We draw from the theory of attitudes from personality psychology (Nakonečný, 2009). Our external impetus is the demonstration of the actual use of ICT within the university lecture, primarily focused on didactic methods. To what extent this simple innovation can be an important trigger for the immediate influence of a change in attitude towards the use of ICT in education is the aim of our research. Digital competence theories are the ethical framework for determining the initial assessment of andragogy students. We find out the initial level of knowledge and skills, the relationship to ICT, but also the frequency of ICT use. We also base our research on the concept of Veteška and Kursch (2018), who summarize that for the success of education in the context of Education 4.0, important factors are "passion for a particular cause" and engagement. And it is these factors that may be related to the phenomenon we are investigating - the change of students' attitudes based on their own experience. The advantage of our research is that our students do not primarily study mathematics or ICT, but andragogy and didactics, so we aim primarily at finding a change in attitude towards the use of ICT in education in an unprofessional group.

\section{Materials and Methods}

A total of 224 students of master's and bachelor's programmes in adult education at the Faculty of Education of Charles University in the Czech Republic participated in the research over a period of 3 years $(2018,2019,2020)$. The participants of the experiment are in our terminology from the introduction "educators" and in the experiment, we will also synonymously call them respondents. The experiment was conducted a total of 8 times in 16 homogeneous groups. The groups were always chosen according to the participants of lectures of programs under andragogical programs according to the possibilities of the university, and if there were more participants in the control group or vice versa, the responses in this group were reduced according to random selection to the number of smaller groups. The groups thus met the homogeneity criteria in terms of the program studied, gender and number of respondents. Table 1 shows the parameters of each group. For the experiment, one of the groups was always experimental and one control. The control group held a seminar aimed at explaining the unconventional didactic method of AIDA on the example of a mathematical problem in the case of the birthday paradox (The birthday paradox is nothing new, more so, for example, in (Al-Khalili, 2012)), but the teaching did not use ICT as a support tool. The experimental group had the same seminar with the same task, but using ICT, namely empirical modelling of the birthday paradox using a simple Python program and modelling in the MS Excel spreadsheet program. For our experiment, we then aggregated all the results of the questionnaire, which was carried out before and after the experiment, into one final control group, consisting of 112 respondents, composed of all sub-control groups and one resulting experimental group of 112 respondents, consisting of all sub-experimental groups (see Table 1).

Table 1

Parameters of each group

\begin{tabular}{llllll}
\hline \multicolumn{1}{c}{ Group } & men & women & SUM & Year & $\begin{array}{l}\text { Degree } \\
\text { Program }\end{array}$ \\
\hline 1 control & 3 & 12 & 15 & 2018 & Bachelor \\
2 experimental & 3 & 12 & 15 & 2018 & Bachelor \\
3 control & 4 & 10 & 14 & 2018 & Bachelor \\
4 experimental & 4 & 10 & 14 & 2018 & Bachelor \\
5 control & 3 & 9 & 12 & 2019 & Master \\
6 experimental & 2 & 10 & 12 & 2019 & Master \\
7 control & 2 & 5 & 7 & 2019 & Master \\
8 experimental & 2 & 5 & 7 & 2019 & Master \\
9 control & 2 & 6 & 8 & 2019 & Master \\
10 experimental & 3 & 5 & 8 & 2019 & Master \\
11 control & 3 & 13 & 16 & 2019 & Bachelor \\
12 experimental & 5 & 11 & 16 & 2019 & Bachelor \\
13 control & 5 & 18 & 23 & 2020 & Master \\
14 experimental & 8 & 15 & 23 & 2020 & Master \\
15 control & 9 & 8 & 17 & 2020 & Master \\
16 experimental & 9 & 8 & 17 & 2020 & Master \\
SUM & $\mathbf{6 7}$ & $\mathbf{1 5 7}$ & $\mathbf{2 2 4}$ & $\mathbf{n} / \mathbf{a}$ & n/a \\
\hline
\end{tabular}

www.ijcrsee.com 
Kursch, M. (2021). Impact of a one-off demonstration on the use of ICT in the teaching of andragogy students on their change of attitude towards the use of ICT in education, International Journal of Cognitive Research in Science, Engineering and Education (IJCRSEE), 9(1), 121-134.

The input data was composed of data from all 112 respondents of the resulting control and experimental groups. By homogeneity of the sub-groups, we guaranteed the overall homogeneity and representativeness of the sample and by merging the sub-groups we achieved the necessary size and sample. We thus created one large control group and one large experimental group consisting of responses from all respondents.

In the experiment, we distinguish four input variables that determine the overall relationship of respondents to ICT, their ICT experience and skills, and four variables researched for which we find the degree of change in attitude towards the use of ICT in education in the experiment. When examining input variables, we considered the concepts of TPCK (Koehler et al., 2013) and DigComp (Vuorikari et al., 2016). We are aware of the different relationship of respondents to ICT and the different initial knowledge and skills in this area. However, it would be very difficult for our research to find out in detail the position of respondents within TPCK and DigComp, or to carry out a deeper assessment, especially for time reasons. Levels of ICT competencies of university students in the Czech Republic, Poland and Slovakia were researched by e.g., Eger et al. (2018) in his comprehensive study. That is why we chose the simplified model and tried to identify four essential input variables for all respondents in all our groups. These variables are related to ICT (positive vs negative), estimation of their ICT skills (excellent vs insufficient), experience in the use of ICT in teaching or education (extensive vs none) and frequency of ICT use in their current work or their studies (very common vs. not at all). Here we base our ideas on Eger et al. (2018), who, based on research, has concluded that "frequencies of ICT use for school and leisure-related tasks are crucial determinants of students' ICT competence". We used a 5-point Likert range to determine the rate of these input variables. Based on the inspection and check-up of input variables, we can detect possible correlations or dependencies on our variables under investigation, as well as possible anomalies in data or non-standard deviations, for example, due to prejudice. We have separated all variables so that our experiment can be repeated at any time, which is why we describe in great detail the AIDA method used and accurately describe the demonstration of the use of ICT for the experimental group.

Before listing specific cases, we provide a short description of the AIDA method (from Attention, Interest, Desire and Action) in teaching. Polk (2018) in his study using the AIDA method demonstrated its positive effects in education. In Table 2, this method is described. The AIDA method in education and the creation of e-learning courses are also used by some commercial organizations (e.g., B-online learning, see https://bonlinelearning.com/using-the-aida-model-to-get-buy-in-elearning/).It can be understood as a didactic method taken from marketing, which, in combination with the use of digital technologies, can arouse the interest of students or pupils in the problem, and itself create an engaging atmosphere in teaching, which can be applied in the introduction to the problem, new teaching or project learning. By combining this method using digital and communication technologies, we can achieve synergistic effects that increase the overall learning efficiency of students and pupils.

Table 2

AIDA method in education

$\begin{array}{ll}\text { Phase } & \text { Phase objective } \\ \text { Attention } & \text { The aim is to create a stir among students or pupils. It can be inferred, for } \\ \text { example, by a riddle, a suitable question, a description of a paradox, a } \\ \text { description of a shocking discovery. This phase is always an input phase } \\ \text { and should not be too long. } \\ \text { The aim is to arouse interest in the given problem, the subject, the task. } \\ \text { This stage always follows the stage of attention and is intended to develop } \\ \text { it. It is a process of explaining, clarifying a problem, a curriculum, or a } \\ \text { project, but not showing its solution. The inducement of interest may be } \\ \text { gradual, so this phase is aimed at clarifying the whole problem in detail. } \\ \text { The goal is to induce desire. At this stage, students and pupils should move } \\ \text { to a state where they want to solve the problem, master the curriculum, } \\ \text { figure out the essence of the matter or start the project. } \\ \text { The aim of this phase is that students and pupils will take action. That they } \\ \text { will create solutions for the problem, for example, using ICT to start } \\ \text { implementing the project, mastering and managing the curriculum. They } \\ \text { will begin to broaden their horizons and continue to ponder the problem on } \\ \text { their own. }\end{array}$


Our andragogy students are also taught this method as a didactic tool. In our experiment, we teach the AIDA method on the problem of the birthday paradox, which is suitable, for example, in the teaching of combinatorics or as a complement to the teaching of probability. However, it also points to a paradox in the estimation by quick-thinking (Kahneman, 2011). It can be used to explain the dysfunction of intuition in seemingly simple tasks. Many students will remember such tasks for life, and therefore they are suitable for the introduction to the issue of paradoxes. In our experiment, all sixteen groups learn all phases of the method, but the last phase of the method - action - is accompanied only by a paper and pencil calculation in eight control groups. For eight experimental groups, ICT is used to the maximum extent possible in the last phase of the method - action. The full use of ICT as a didactic tool is incorporated into the action phase. The first action of educators in all groups is therefore a mathematical calculation. For this, a simple calculator is enough, but only for one $n$ at a time. This ends the control groups. Experimental groups continue modelling case for different $n$ and educators are assigned a modelling task in the MS Excel spreadsheet program. In Figure 1, you can see very well the results of this modelling, solutions for different $n$. Educators realize that the probability does not grow linearly, and even at 47 people, it reaches a staggering $95 \%$, which often inspires astonishment.

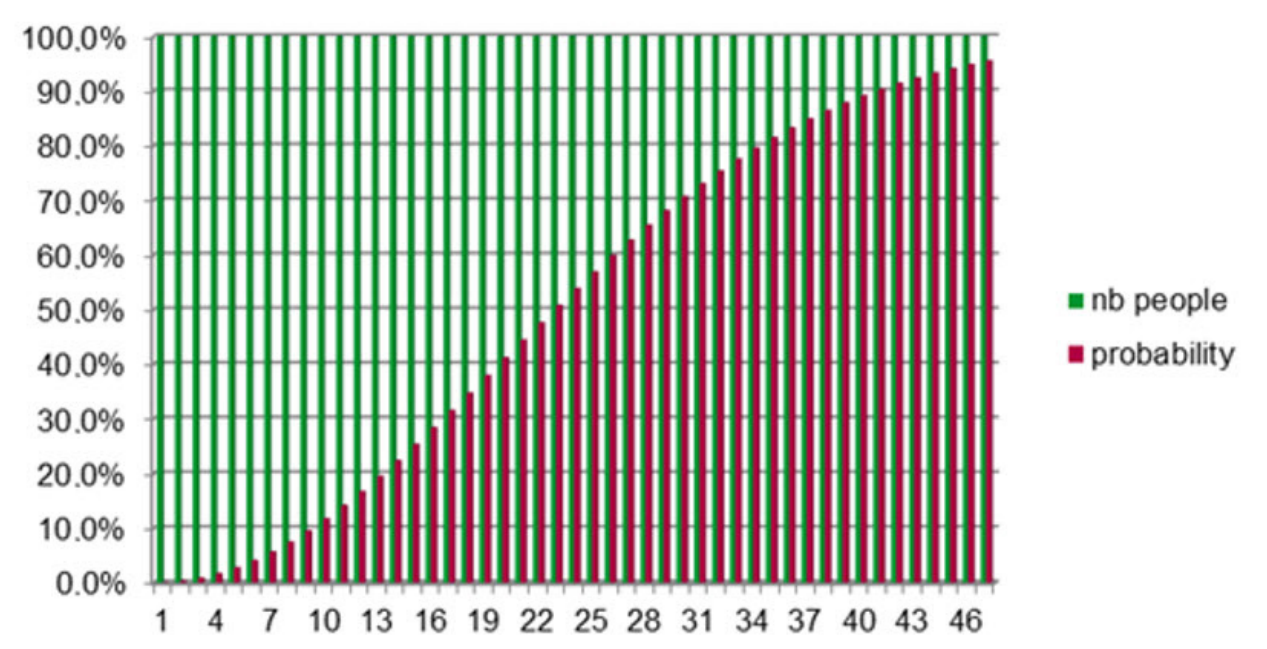

Figure 1. Solving the birthday paradox task for different n ("nb" means "number of").

From our experience, we still meet students who, despite the mathematical calculation mirrored in the Excel table, doubt it. This task is counter-intuitive, so it is advisable to use another ICT tool for empirical verification. For example, there is a widely used tool - Python programming language. For our task, we have used the Python programming language in the Jupyter (https://jupyter.org/try) online environment, which requires no installation and can be operated online on the web. For modelling via the Python program created by us, we can enter the number of randomly selected people and the number of repetitions of the experiment with this group. Such a model induces a real situation. Below is a program that is written in such a way that even students who do not program themselves can trust it and understand it. Therefore, it is a good idea to explain the program line by line, preferably using embedded notes.

importing random \#loading module to generate random numbers keyboard

people = int(input("number of people selected:")) \#setting number of groups of people from the

attempt = int(input("count retries:")) \#setting number of attempts from the keyboard

match $=0$ \#initiation number of birthdays matches at the beginning zero match

for $\mathrm{i}$ in range(attempt): \#cycle conducting experiments

$b=[]$ \#set $b$ days of birth of randomly selected people

for $y$ in range(people): \#cycle fulfilling set of dates of birth (order of days in the year)

day $=$ random.randint $(1,365)$ \#random date selection

if day in b: \#if date already exists in the set,

match $+=1$ \#then one match is added 
Kursch, M. (2021). Impact of a one-off demonstration on the use of ICT in the teaching of andragogy students on their change of attitude towards the use of ICT in education, International Journal of Cognitive Research in Science, Engineering and Education (IJCRSEE), 9(1), 121-134.

break \#a goes on another try

b.append(day) \#else date is assigned to set $b$ at the end

print(f'In \{attempt\} attempts, \{match\} could be found")

print(f'In \{attempt $\}$ attempts, match ability was $\{$ match*1000//attempt/10\} \%") \#writes off test results

Students can then try to enter different number of attempts and groups online. For example, for $n=10$ to 80 . Table 3 shows the results of the outputs of the program for different $n$.

Table 3

Results of randomly selected groups of people who matched birthdays

\begin{tabular}{llllll}
\hline experiments/people & $\mathbf{n}=\mathbf{1 0}$ & $\mathbf{n}=\mathbf{2 3}$ & $\mathbf{n}=\mathbf{3 0}$ & $\mathbf{n}=\mathbf{6 0}$ & $\mathbf{n}=\mathbf{8 0}$ \\
\hline $\mathbf{1 0 0}$ & $11.0 \%$ & $46.0 \%$ & $73.0 \%$ & $98.0 \%$ & $100.0 \%$ \\
$\mathbf{1 0 0 0}$ & $11.3 \%$ & $51.6 \%$ & $68.7 \%$ & $99.5 \%$ & $100.0 \%$ \\
$\mathbf{1 0 0 0 0}$ & $11.8 \%$ & $51.1 \%$ & $70.9 \%$ & $99.4 \%$ & $99.9 \%$ \\
$\mathbf{1 0 0 0 0 0}$ & $11.6 \%$ & $50.6 \%$ & $70.4 \%$ & $99.4 \%$ & $99.9 \%$ \\
\hline
\end{tabular}

Such verification can no longer be doubted, and the proof is valid. In this example, the use of ICT for teaching is also a demonstration of a powerful tool that we would find very difficult to supersede in real life. One hundred thousand attempts in one minute were an unthinkable dream decades ago. But why did we choose the AIDA method? Why did we use the role of the birthday paradox? We wanted to minimize any negative effects of an inappropriately chosen method that does not in itself appeal to students, that will be boring or untested. This method, combined with an unconventional role that carries a paradox, guarantees a high motivation of andragogy students and their maximum interest. As a result, we are very likely to exclude other unwanted factors that could act as other variables representing disturbing elements.

For research questions, we set the following zero hypotheses:

HAO: Demonstration of the use of ICT in the teaching of andragogy students does not affect their opinion on the impact of ICT use on education and learning itself.

HBO: Demonstration of the use of ICT in the teaching of andragogy students in teaching does not affect the convictions of andragogy students to use ICT in teaching.

HCO: Demonstration of the use of ICT in the teaching of andragogy students in teaching does not affect their inclination to act to recommend the use of ICT in teaching to their colleagues.

HDO: Demonstration of the use of ICT in the teaching of andragogy students does not affect their opinion on the impact of the use of ICT on the understanding of teaching.

Finally, in Figure 2, we present a framework diagram of our experiment, including capturing the entire experiment process. The method for measuring input variables was a questionnaire using a 5-point Likert scale. The method for measuring the variables under study during the experiment was the bipolar 10-point scale. It is a scale that can measure the dimensions of the respondent's attitude towards ideas, concepts, subjects, people, etc. A non-parametric test for categorical variables - goodness of fit test - was selected as a test statistic. The same methodology was used for all divided groups in all 3 years. As a criterion for changing the overall attitude towards the use of ICT in education in respondents, we chose the condition that we reject at least three out of four zero hypotheses. Otherwise, we will consider the attitude towards the use of ICT in education unchanged. The research tool of initial assessment as well as of experiment part was designed by the researcher according to his previous studies (Veteška and Kursch, 2018). The tool shows internal coherence. Initial assessment includes 4 variables of evaluation and shows coherence - McDonald's $\omega=0.745$; Cronbach's $\alpha=0.766$; Gutmann's $\lambda 6=0.776$. The experiment part includes 1 item - attitude towards the use of ICT in education which consists of 4 variables (representing dimensions of attitude) and shows coherence before experiment - McDonald's $\omega=0.896$; Cronbach's $\alpha=0.893$; Gutmann's $\lambda 6=0.886$ and after experiment - McDonald's $\omega=0.902$; Cronbach's $\alpha=0.899 ;$ Gutmann's $\lambda 6=0.877$. 
Kursch, M. (2021). Impact of a one-off demonstration on the use of ICT in the teaching of andragogy students on their change of attitude towards the use of ICT in education, International Journal of Cognitive Research in Science, Engineering and Education (IJCRSEE), 9(1), 121-134.

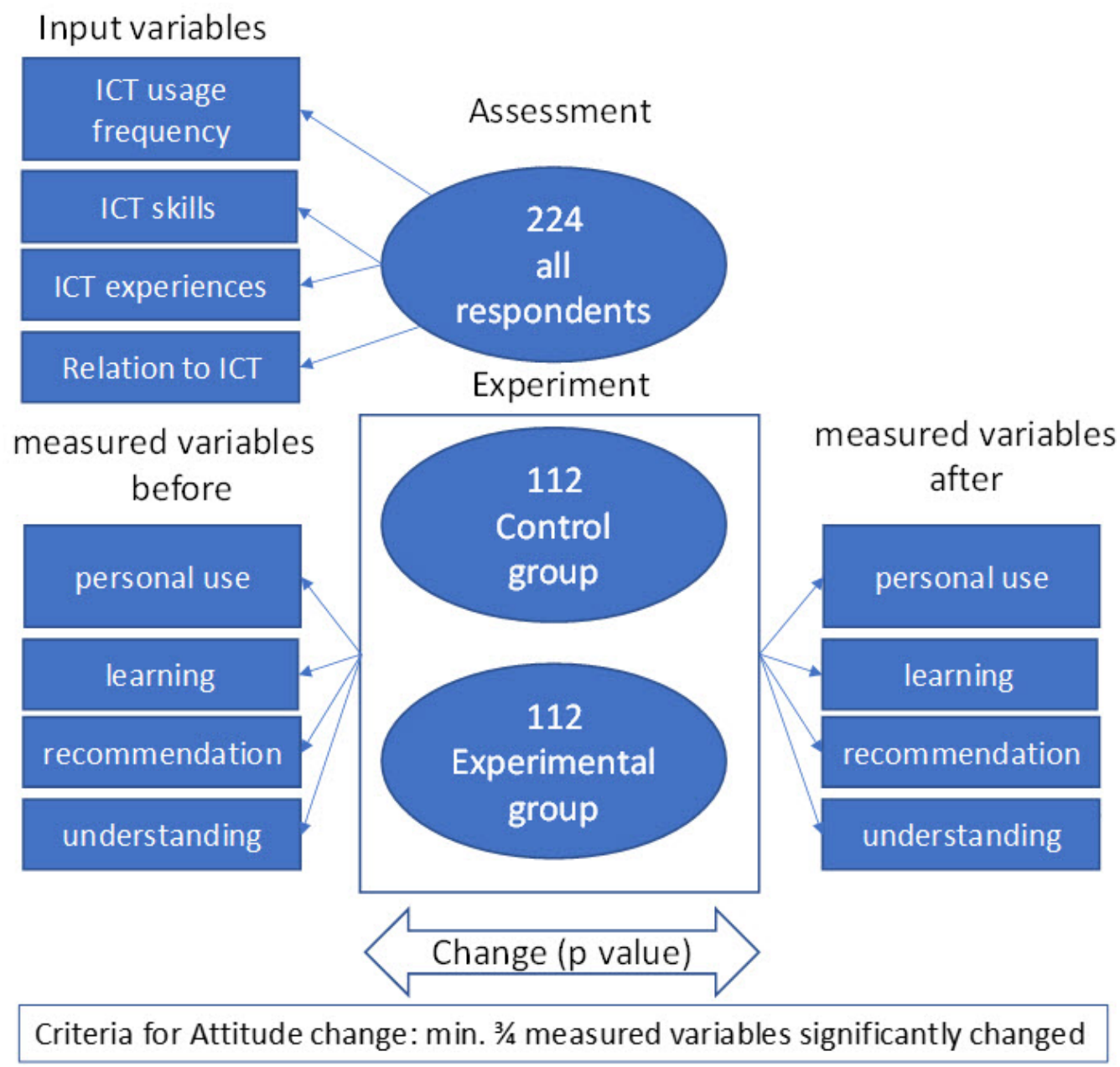

Figure 2. Experiment description schema.

\section{Results}

First, we present the results of our respondents' input responses. Respondents commented on questions about their relationship to ICT, estimation of their skills in the use of ICT, their experience in the use of ICT in teaching or education and the frequency of use of ICT in their current job. Answers to all 4 key questions are categorized in Figure 3. 5-point Likert scales with the following key were chosen for the assessment: skills (1 - excellent 5 - insufficient), attitude to ICT (1 - very positive 5 - very negative), experience (1 - extensive 5 - none), frequency of ICT usage (1 - very often 5 - not at all).

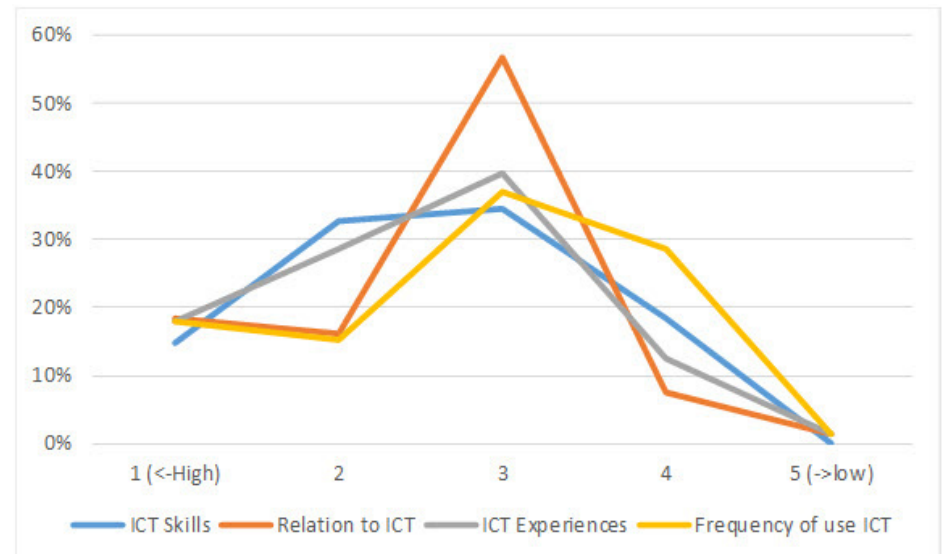

Figure 3. Respondents' responses to their ICT skills, the experience of using ICT in teaching, frequencies of use of ICT in work and their relationship to ICT (scale 1-5). 
Kursch, M. (2021). Impact of a one-off demonstration on the use of ICT in the teaching of andragogy students on their change of attitude towards the use of ICT in education, International Journal of Cognitive Research in Science, Engineering and Education (IJCRSEE), 9(1), 121-134.

The input responses allowed us to find possible disruptive phenomena or prejudices of respondents that could then explain the extreme values measured during the experiment. In our case, however, we found no anomalies. Table 4 shows relations among input variables via similarity matrix.

Table 4

Similarity matrix (created with IBM SPSS Statistics based on Pearson's correlations)

\section{Proximity Matrix}

Rescaled Correlation between Vectors of

\begin{tabular}{ccccc} 
& \multicolumn{4}{c}{ Values } \\
relation & skills & experience & frequency \\
relation & 1.000 & 0.588 & 0.807 & 0.815 \\
skills & 0.588 & 1.000 & 0.782 & 0.741 \\
experience & 0.807 & 0.782 & 1.000 & 0.830 \\
frequency & 0.815 & 0.741 & 0.830 & 1.000 \\
\hline
\end{tabular}

However, from the results of the experiment, we found very interesting findings regarding our researched dimensions of the attitude of andragogy students on the use of ICT in the education. As a test hypothesis of the experiment, we used the Chi-Square goodness of fit test. We calculated the comparison of expected and measured values for each individual before and after using a goodness of fit test. The expected test value (considered for each individual as their initial pre-teaching input value) and the experimental measured value (the actual value measured after teaching in both the control and experimental groups for each individual) were measured on a 10-point bipolar scale. The degrees of freedom were 111, as each respondent is part of one value. Critical values match levels $\alpha=0.05, a=0.01$ and degrees of freedom:

$\chi^{2} 0.95(111)=136.591$
$\chi^{2} 0.99(111)=148.571$

In the experimental group, we look for all values (Values $\chi^{2}$ motivation (162.439), understanding (136.140), recommendations (139.870), impact (160.619)) greater $\chi^{2}>\chi^{2} 0.95(111)$ which imply the difference between the detected and expected frequency is statistically significant at a significance level of 0.05 . On the contrary, for the control group, all values (Values $x 2$ motivation (75.276), understanding (22.117), recommendations (16.582), impact (73.267)) are $\chi^{2}<\chi^{2} 0.95(111)$. We therefore refuted 3 zero hypotheses $\mathrm{HAO}, \mathrm{HBO}$ and $\mathrm{HCO}$. Table 5 shows the results of the goodness of fit test for the experimental and control groups.

Table 5

Research results for experimental and control groups for our examined factors ( $p$ values)

\begin{tabular}{ccccc}
\hline ICT in teaching ( $\mathrm{p}$ values) & Personal use & Understanding & Recommendations & Learning \\
\hline control group & 0.9962 & 1.0000 & 1.0000 & 0.9978 \\
experimental group & 0.0011 & 0.0528 & 0.0332 & 0.0015 \\
\hline
\end{tabular}

Assuming that the variables under examination give us an equal indication of a change in attitude towards the use of ICT in education and the fulfilment of our established refutation criterion of at least three out of four zero hypotheses, we can conclude that we have demonstrated a statistically significant positive effect of the demonstration of the use of ICT in teaching of andragogy students on their change in attitude towards the use of ICT in education. In more detail, a statistically significant positive effect on the change in the cognitive dimension of attitude towards the use of ICT in education - an opinion on the impact on education and learning itself, a positive effect on the change in the conative dimension of attitude towards the use of ICT in education - a tendency to recommend to colleagues the active use of ICT in teaching and education, and a change in the emotional dimension - the conviction to use ICT more in their future teaching. Only for the influence on the change in the cognitive dimension of attitude towards the use of ICT in the education of andragogy students - the opinion on the impact of the use of ICT in teaching on the understanding of curriculum was $p>0.05$. Therefore, we could not unequivocally refute 
the zero hypothesis HD0, but it should be noted that $p$, in this case, was $p=0.0528$, i.e., we are at the limit of statistical significance. According to our established criteria, we confirmed the overall signification of the ICT demonstration in teaching on changes in attitudes towards the use of ICT in education among andragogy students. Furthermore, we found that for students who reported their relationship to ICT itself as negative or very negative (input variable), the demonstration of teaching using ICT did not have a significant impact on their change in attitude towards the use of ICT in education. This has been confirmed for all dimensions. This was also the case for respondents reporting little or insufficient skills, very little experience of using ICT in teaching and low frequency of ICT use in teaching. Our results confirming statistical insignificance for these groups are given in Table 6 . These findings could indicate that a negative relationship with ICT and a lack of skills may indicate resistance to a change in attitude towards the use of ICT in education, even after demonstrating the use of ICT in teaching, its effectiveness and positive aspects. However, for such conclusions, we would need further research aimed at finding this correlation or causality.

\section{Table 6}

Research results for the experimental group where respondents gave a negative relationship to ICT, low or insufficient ICT skills, poor experience using ICT in teaching and low frequency of ICT use in teaching ( $p$ values)

\begin{tabular}{ccccc}
\hline ICT in teaching ( $p$ values) & Personal use & Understanding & Recommendation & Learning \\
\hline 4.5 ICT relationship & $p>0.05$ & $p>0.05$ & $p>0.05$ & $p>0.05$ \\
4.5 usage rate & $n / a$ & $p>0.05$ & $p>0.05$ & $p>0.05$ \\
4.5 skills & $n / a$ & $p>0.05$ & $p>0.05$ & $p>0.05$ \\
\hline
\end{tabular}

A complementary fact was that there are no significant statistical differences between men and women. For completeness, we conducted coherence of questionnaire of psychometric properties to verify the reliability of the entire test, covering the researched variables containing responses according to the 10-point bipolar scale, which was 0.893 before and 0.899 after experiment. Cronbach's Alpha has been calculated classically with the omission of one item. IBM SPSS Statistics (build 1.0.0.1447) software was used for the calculation as well as all other values mentioned in part of research tool description. Descriptive statistics of our responses before and after the experiment are given in Table 7.

Table 7

Descriptive statistical parameters of the responses (values 1-10) to be answered before and after the experiment was conducted in both groups.

\begin{tabular}{cccccccccc}
\hline Item & $\mathrm{N}$ & Sum & Average & Median & Modus & Sd & Var & Min & Max \\
\hline before 1 & 224 & 1202 & 5.37 & 5 & 5 & 2.10 & 4.39 & 1 & 8 \\
before 2 & 224 & 1119 & 5.00 & 5 & 5 & 1.71 & 2.93 & 2 & 8 \\
before 3 & 224 & 1319 & 5.89 & 5 & 8 & 2.27 & 5.17 & 1 & 10 \\
before 4 & 224 & 1294 & 5.78 & 5 & 5 & 2.27 & 5.17 & 1 & 10 \\
after 1 & 224 & 1370 & 6.12 & 6 & 5 & 1.99 & 3.97 & 1 & 9 \\
after 2 & 224 & 1362 & 6.08 & 6 & 5 & 1.96 & 3.82 & 2 & 10 \\
after 3 & 224 & 1569 & 7.00 & 7 & 5 & 2.36 & 5.59 & 1 & 10 \\
after 4 & 224 & 1556 & 6.95 & 6 & 5 & 2.39 & 5.72 & 1 & 10 \\
\hline
\end{tabular}

Let us review the goals we set at the beginning of this study. Research questions related to the research problem $P$, what is the influence of a one-off demonstration of the use of ICT in teaching of andragogy students on change of their attitude towards the use of ICT in the field of education.

- Q1: Does a one-off demonstration of the use of ICT in university teaching influence the opinion of andragogy students about the impact of the use of ICT on the understanding of curriculum and education and learning itself?

Our findings show that demonstration of the use of ICT in teaching influences a change in the 
Kursch, M. (2021). Impact of a one-off demonstration on the use of ICT in the teaching of andragogy students on their change of attitude towards the use of ICT in education, International Journal of Cognitive Research in Science, Engineering and Education (IJCRSEE), 9(1), 121-134.

cognitive dimension of attitude towards the use of ICT in the education of andragogy students about the impact of ICT use on the understanding of curriculum and education and learning. Change of opinion on the impact of the use of ICT on education and learning itself can be statistically significant $(p<0.05)$, for the experimental group the point value of the 10-point bipolar scale increased by 1.879 on average, as opposed to the control group, where it increased by only 0.375 points. The knowledge of the change of opinion on the understanding of curriculum through the use of ICT also supports a positive answer to the question regarding the decisive role of ICT to understand the current problem, although we cannot confirm statistical significance ( $p>0.05$ ) based on the results. However, we cannot rule out a high degree of influence, because in this case, the experimental group on the 10-point bipolar scale gave values in an average of 1.805 higher after the experience with ICT in solving the task of the birthday paradox (measured $p$ was 0.0528 ).

- Q2: Does a one-off demonstration of the use of ICT in university teaching influence the immediate conviction of andragogy students to use ICT in their future teaching?

In the question aimed at determining the influence of the change in the emotional dimension of students' attitudes towards the use of ICT in education - the conviction to use ICT in their future teaching based on their own experience with it and its use in didactics teaching, the results were unequivocal. The change in conviction in the use of ICT in their future teaching in the experimental group represents a higher increase in the 10-point bipolar scale compared to the control groups. On average, the score for the experimental group increased by 1.097 points compared to the control group, where it increased by 0.389 points. Here we could point out that the conviction to use ICT in teaching increases after a specific demonstration and understanding the importance of using ICT in a didactic process as opposed to ignorance of such an impact in control groups. Nevertheless, we remind you that based on the analysis of input variables, this effect is measurable only for students with a positive relationship to ICT.

- Q3: Does a one-off demonstration of the use of ICT in university teaching influence recommending the use of ICT in teaching to their colleagues?

The change in the conative dimension of the attitude towards the use of ICT in education - the tendency to act to recommend the active use of ICT in teaching and education to their colleagues confirms to us that, together with the change of conviction in the use of ICT in their teaching, the tendency to act to recommend the use of ICT tools in teaching to their colleagues increases. It is an interesting phenomenon that one demonstration was enough to increase the recommendation rate. The 10-point bipolar scale averages 1.831 change for the experimental group versus 0.380 for the control group. This finding may point to the fact that careful and fair teaching of the use of ICT for andragogy students positively influences the spread of good practices among other educators. We can also assume that thanks to the recommendations, the expansion of effective ICT teaching tools among educators - educators and adult educators across many disciplines of teaching can happen.

\section{Discussions}

Based on the results of our experiment, using statistical analysis, we confirmed 3 hypotheses that there are positive links between the demonstration of the use of ICT in teaching and the change of attitude towards the use of ICT in education by andragogy students. This means that the use of ICT in the teaching of future educators will lead to a higher use of ICT in their own teaching and to the promotion of the use of ICT in education. This result is in line with some recent previous studies on the positive effects of ICT use in teaching (Hardman, 2019; Mlambo, Rambe and Schlebusch, 2020 ; Willis et al., 2019; Hammond, 2017; Garzón et al., 2020) and attitude towards the use of ICT in education (Eksail and Afari, 2020; Tomczyk et al., 2020b).

Our study should be evaluated in terms of objectivity and consider any valid objections to the research itself. In our research, we paid attention to the separation of variables. The groups were homogeneous in terms of the distribution of men and women of the same number of respondents and in terms of the diversity of the input parameters of our respondents - andragogy students. The selection of individual participants of the group was random from the beginning, included in the given university division by subject. We looked at three dimensions of attitude towards the use of ICT in education, represented by four variables: the conviction to use ICT in teaching; opinion on the impact of ICT use on the understanding of curriculum, opinion on the impact of the use of ICT on education and learning itself; and the inclination to act to recommend it to their colleagues in teaching. We also looked at the input parameters of respondents' relationship to ICT as a default state to separate possible relations with the student's prejudices on ICT as such or to eliminate abnormalities. We asked test questions to identify four 
factors to experimental and control groups at the same time, a week before their experimental teaching and a week after their teaching. Thanks to the minimum time interval, we eliminated other possible influences during this time, but at the same time, we eliminated the immediate effect of responses "just" after experimental teaching. Separation and balancing with the time interval thus performed ensured the maximum possible independent results. Thanks to the anonymization of respondents, it is also impossible to object to the possible influence of authorities. Furthermore, we used the most attractive content of didactics to eliminate any lack of interest of respondents in the content of the study. The relevant objection may then be the introduction of respondents to the subject of the research and its purpose, but this should not affect the differences in responses, since even the initial state was detected after the initial communication, but with a gap of weeks, since the communication was carried out at the beginning of the term.

What we see as a key challenge for our research is whether our identified influence is permanent or only temporary, induced by a positive experience and a one-off teaching experience. We would certainly suggest further research in this area, regarding this issue. It would be advisable to repeat our experiment to confirm the results mentioned by us and to carry out new research to determine the permanence of positive influence. ICT certainly has a great future in education and learning. In particular, new ICT such as augmented reality, virtual reality has promising results in its use in the field of education and learning. Therefore, we should go down the path of increasing digital competencies (Hanafi et al., 2017) of our future educators and adult educators. The development of digital competences is essential for the application of the individual within the profession, but also in social and civic roles (Veteška, 2016). It will take constant improvement, adaptation and rational approach so that we do not get into extreme positions, prevent inefficiencies and help build an environment in which all educational participants feel comfortable working with ICT and their practical applications on this path.

\section{Conclusions}

Our results have come to explicit conclusions that confirm the positive effects of the demonstration of the use of ICT in teaching to change the attitude of andragogy students on the use of ICT in education. These changes are particularly reflected in students with an "a priori" positive relationship to ICT. Our specific recommendation is to focus in particular on demonstrating the use of ICT in education in the areas of real-world modelling using simple programs or applications, simulation of real events in virtual laboratories, solving complex problems using advanced big data processing tools and dynamic visualizations of the results of real-world variable relationships. If our research were to be repeatedly confirmed, we could realize that, from a didactic and methodological point of view, demonstration of the use of ICT in teaching as a tool for understanding of curriculum or solving the problem is an effective means of influencing changes in attitudes towards the use of ICT in education, and thus an argument to include these demonstrations across university subjects for andragogy students (andragogy students, educators, education advisers, education managers, principals and others). The results could give impetus to the more frequent inclusion of the use of ICT in university teaching of future and current educators to enrich this teaching with interesting and effective didactic ICT tools, which will then be promoted by university graduates themselves across many disciplines and specializations.

\section{Acknowledgements}

We would like to thank all those who have contributed to the carrying out of this study. Special thanks to Prof. Jaroslav Veteška from Department of Andragogy and Educational Management Faculty of Education of Charles University in Prague. This study was supported by the Technology Agency of the Czech Republic (TAČR: TL03000133).

\section{Conflict of interests}

The author declares no conflict of interest.

\section{References}

Al-Khalili, J. (2012). Paradox: the nine greatest enigmas in physics: the nine greatest enigmas in physics. Broadway: Transworld Digital.

Brdička, B. (2004). Vliv technologií na inovaci výukových metod [The influence of technology on the innovation of teaching 
Kursch, M. (2021). Impact of a one-off demonstration on the use of ICT in the teaching of andragogy students on their change of attitude towards the use of ICT in education, International Journal of Cognitive Research in Science, Engineering and Education (IJCRSEE), 9(1), 121-134.

methods] [Online]. In Spomocník.net. Retrieved March 29, 2021, from http://www.spomocnik.net/2004/12/vlivtechnologii-na-inovaci-vyukovych.html

Brdička, B. (2009). Článek teoreticky popisující model integrace technologií do portfolia kompetencí učitelů [An article theoretically describing the model of technology integration into the portfolio of teacher competencies] [Online]. In Metodický portál RVP.CZ. Retrieved from https://spomocnik.rvp.cz/clanek/10641/INTEGRACE-TECHNOLOGIIPODLE-MODELU-TPCK.html

Chang, C. T., Tu, C. S., \& Hajiyev, J. (2019). Integrating academic type of social media activity with perceived academic performance: A role of task-related and non-task-related compulsive Internet use. Computers \& Education, 139, 157172. https://doi.org/10.1016/j.compedu.2019.05.011

Čok T. (2016). ICT-supported language learning tools for Chinese as a foreign language. Journal of Elementary Education, 9(3), 103-120. Retrieved from https://journals.um.si/index.php/education/article/view/353

Çoklar, A. N. (2013). Areas affected most by the students from the ICT focused technological transformations and its effects on education. Mediterranean Journal of Social Sciences, 4(9), 249-252. https://doi.org/10.5901/mjss.2013.v4n9p249

Eger, L., Klement, M., Pisoňová, M., \& Petrová, G. (2018). Different user groups of university students and their ict competence: evidence from three countries in central Europe. Journal of Baltic Science Education, 17(5), 851. https:// doi.org/10.33225/jbse/18.17.851

Eger, L., Tomczyk, Ł., Klement, M., Pisoňová, M., \& Petrová, G. (2020). How do first year university students use ICT in their leisure time and for learning purposes? International Journal of Cognitive Research in Science Engineering and Education, 8(2), 25-52. https://doi.org/10.5937/IJCRSEE2002035E

Eksail, F. A. A., \& Afari, E. (2020). Factors affecting trainee teachers' intention to use technology: A structural equation modeling approach. Education and Information Technologies, 25(4), 2681-2697. https://doi.org/10.1007/s10639-019-10086-2

Garzón, J., Baldiris, S., Gutiérrez, J., \& Pavón, J. (2020). How do pedagogical approaches affect the impact of augmented reality on education? A meta-analysis and research synthesis. Educational Research Review, 31. https://doi.org/10.1016/j. edurev.2020.100334

Genlott, A. A., \& Grönlund, Å. (2016). Closing the gaps - Improving literacy and mathematics by ICT-enhanced collaboration. Computers, 99, 68-80. https://doi.org/10.1016/j.compedu.2016.04.004

Hammond, M. (2017). Online collaboration and cooperation: The recurring importance of evidence, rationale and viability. Education and Information Technologies, 22(3), 1005-1024. https://doi.org/10.1007/s10639-016-9469-x

Hanafi, H. F., Said, C. S., Wahab, M. H., \& Samsuddin, K. (2017, August). Improving students' motivation in learning ICT course with the use of a mobile augmented reality learning environment. In IOP Conference Series: Materials Science and Engineering (Vol. 226, No. 1, p. 012114). IOP Publishing. https://doi.org/10.1088/1757-899X/226/1/012114

Hardman, J. (2019). Towards a pedagogical model of teaching with ICTs for mathematics attainment in primary school: A review of studies 2008-2018. Heliyon, 5(5), e01726. https://doi.org/10.1016/j.heliyon.2019.e01726

Kahneman, D. (2011). Thinking, fast and slow. New York: Farrar, Straus and Giroux.

Koehler, M. J., Mishra, P., Akcaoglu, M., \& Rosenberg, J. (2013). The Technological Pedagogical Content Knowledge Framework for Teachers and Teacher Educators. In R. Thyagarajan, ICT integrated teacher education: A resource book (pp. 2-7). New Delhi: Commonwealth Educational MediaCentre for Asia. Retrieved from http://cemca.org.in/resources/books

Kursch, M., \& Veteška, J. (2019). Paradigma „Vzdělávání 4.0“ v éře digitalizace a globalizace [Paradigm "Education 4.0” in the era of digitization and globalization]. In J. Veteška (ed.). Vzdělávání dospělých 2018 - transformace $v$ ére digitalizace a umélé inteligence = Adult Education 2018 - transformation in the era of digitization and artificial intelligence: proceedings of the $8^{\text {th }}$ International Adult Education Conference, 11-12th December 2018 Prague (pp. 15-23). Praha: Ceská andragogická společnost.

Mlambo, S., Rambe, P., \& Schlebusch, L. (2020). Effects of Gauteng province's educators' ICT self-efficacy on their pedagogical use of ICTS in classrooms. Heliyon, 6(4), e03730. https://doi.org/10.1016/j.heliyon.2020.e03730

Nakonečný, M. (2009). Psychologie osobnosti [Psychologie osobnosti] (2nd ed.). Praha: Academia.

Polk, X. L. (2018). Marketing: The Key to Successful Teaching and Learning. Journal of Marketing Development, $12(2), 49-57$. https://doi.org/10.33423/jmdc.v12i2.1257

Siemens, G. (2005). Connectivism: A learning theory for the digital age. International Journal of Instructional Technology \& Distance Learning, 2(1), 3-10. Retrieved from http://www.itdl.org/journal/jan_05/article01.htm

Snijders, D., van der Duin, P., Marchau, V., \& van Doorn, G. J. (2018). Scenarios for ICT-related education: a qualitative metaanalysis. Journal of Futures Studies, 23(2), 13-28. https://doi.org/10.6531/JFS.201812 23(2).0002

Takada, S., Cuadros-Vargas, E., Impagliazzo, J., Gordon, S., Marshall, L., Topi, H., ... \& Waguespack, L. (2020). Toward the visual understanding of computing curricula. Education and Information Technologies, 25(5), 4231-4270. https://doi. org/10.1007/s10639-020-10127-1

Talan, T. (2020). The effect of mobile learning on learning performance: A meta-analysis study. Educational Sciences: Theory and Practice, 20(1), 79-103. https://doi.org/10.12738/jestp.2020.1.006

Tomczyk, Ł., Jáuregui, V. C., Amato, C. A. D. L. H., Muñoz, D., Arteaga, M., Oyelere, S. S., ... \& Porta, M. (2020a). Are teachers techno-optimists or techno-pessimists? A pilot comparative among teachers in Bolivia, Brazil, the Dominican Republic, Ecuador, Finland, Poland, Turkey, and Uruguay. Education and Information Technologies, 1-27. https://doi. org/10.1007/s10639-020-10380-4

Tomczyk, Ł., Martins, V. F., Eliseo, M. A., Silveira, I. F., Cibelle, A., Stošić, L., \& Oyelere, S. S. (2020b). How Does the Attitude to New Media influence the Evaluation of a new e-Learning Platform Among Current and Future Teachers?. In 2020 XV Conferencia Latinoamericana de Tecnologias de Aprendizaje (LACLO) (pp. 1-8). IEEE. https://doi.org/10.1109/ LACLO50806.2020.9381130

Veteška, J. (2016). Přehled andragogiky [Overview of andragogy]. Praha: Portál.

Veteška, J., \& Kursch, M. (2018). The research on the efficiency of the methods of talent management within organizations. New Educational Review, 52(2), 28-42. https://doi.org/10.15804/tner.2018.52.2.02

Vuorikari, R., Punie, Y., Gomez, S. C., \& Van Den Brande, G. (2016). DigComp 2.0: The digital competence framework for citizens. Update phase 1: The conceptual reference model (No. JRC101254). Joint Research Centre (Seville site). https://doi.org/10.2791/11517 
Kursch, M. (2021). Impact of a one-off demonstration on the use of ICT in the teaching of andragogy students on their change of attitude towards the use of ICT in education, International Journal of Cognitive Research in Science, Engineering and Education (IJCRSEE), 9(1), 121-134.

Wang, J., Tigelaar, D. E., \& Admiraal, W. (2021). Rural teachers' sharing of digital educational resources: From motivation to behavior. Computers \& Education, 161, 104055. https://doi.org/10.1016/j.compedu.2020.104055

Willis, R. L., Lynch, D., Fradale, P., \& Yeigh, T. (2019). Influences on purposeful implementation of ICT into the classroom: An exploratory study of K-12 teachers. Education and Information Technologies, 24(1), 63-77. https://doi.org/10.1007/ s10639-018-9760-0

Zhang, L., Basham, J. D., \& Yang, S. (2020). Understanding the implementation of personalized learning: A research synthesis. Educational Research Review, 31. https://doi.org/10.1016/j.edurev.2020.100339 